\title{
Religião, política e cultura
}

Joanildo A. Burity

Esteartigo sepropõea ser uma metareflexão sobrea construção de uma interrogação quanto ao vínculo entre religião e política na contemporaneidade. Embora irrecusavelmente sua provocação emerja da circunstância de o autor ser brasileiro, socializado cultural, política e academicamente na conjuntura dos anos de 1980 em diante, a análisenão seatém ao contexto brasileiro. N ão nego - digo logo - quehá al go "biográfico" na construção narrativa ena evolução argumentativa que o texto proporá. M as quero crer que há al go mais, na pior das hipóteses um testemunho que pode ser tomado como uma posição intelectual ou como um depoimento para interessados na história ou sociologia dos estudos científico-sociais da religião; na mel hor, uma proposta de disciplina do olhar eda reflexão para capturar um objeto em reconfiguração o campo das relações entre religião e política. Enfim, afirmo, rememoro e proponho um caminho de análise para o tema em questão; convoco interlocutores; apresento filiações; sugiro pistas que, me parece, tornam a reflexão proposta um convitea revermos não só nossos cotidianos exercícios de observação do mundo de que participamos, mas também o que outros observadores- de preferência os acadêmicos- estão dizendo a respeito dele.

0 texto organiza-se na seguinte seqüência de interrogações, que apresento da forma mais prosaica possível: 0 que vemos entre religião e política na contemporaneidade? Como nos posicionamos - para ver e em face de que vemos? Q ue lugar é este, do/no qual vemos? 
1. A rigor, apenas recentementeesse plural tem sido admitido, na esteira de certa guinada cultural nas ciências sociais, que permitiu maior atenção a fenômenos que haviam sido simplesmente invisibilizados pelos enfoquesmacrossocietários e histórico-estruturais herdados do século XIX eda primeira metade do sé culo XX (cf. N unes, 2002; $M$ ato, 2004; H ermet, 2002; Tomassini, 2000). A religião, no singular efundamentalmentepensada desde o registro ocidental das formas históricas do cristianismo, era o objeto daquela análise científico-social. N os últimosanos, a atenção à pluralidade e à diferença tem levado a uma percepção de que o objeto "religião" não éunificado (cf. Burity, 2003b; Parker G., 1999; Filoramo e Prandi, 2003).
No que direi sobre "ver", em seguida, desde logo advirto minha nãoingenuidade: junto-meàqueles(as) que compreendem a "observação" como co-implicação, co-[i]nspiração. Ver não é contemplar de longe, nem mesmo para o historiador das mais remotas épocas e lugares. $\mathrm{N}$ ão fosse pelas aporias crescentemente surgidas ou reveladas pelos pressupostos epistemológicos, métodos e resultados das ciências sociais objetivistas, nossos próprios compromissos e interpelações no tempo e no lugar em que vivemosjá nos deveriam advertir para isso. Pois, aqui e agora (coordenadas que, para cada um[a] de nós, possuem extensão e profundidade variáveis) estamos todos às voltas com os outros, suasfacessuplicantes, suas vozes demandantes, seus corpos desejantes, e os numerosos contextos em que sua mera existência cobra sentido coletivo (modos de vida; dinâmicas institucionais; repertórios de ação, conflitos e articulação de demandas etc.). Vejamos, portanto, sabendo-nos parte (interessada) do que vemos...

\section{0 que se dá a ver, como o vemos?}

$\mathrm{N}$ ão se pode mais ignorar a visibilidade pública da religião na cena contemporânea. Q uer no plano da cultura e do cotidiano, quer no da esfera pública eda política, os atores religiosos movimentam-se etrazem a público sua linguagem, seu ethos, suas demandas, nas mais diversas direções. 0 ra esses processos contribuem para caracterizar formas pluralistas e dialógicas de convivência e de enfrentamento de problemas sociais e políticos, ora apontam para o estreitamento dos canais de comunicação e para a escalada da violência e da intolerância. Em muitos países, organizações, movimentos e pessoas ligadas a diferentes religiões ocupam espaços de representação e de participação, em seu próprio nomeou como parteda sociedadecivil organizada. C ontrovérsias sobre a legitimidade ou não de usose críticas da religião no plano das manifestações culturais, do acesso à mídia ou da sociedade política tornam-seclaramente visíveis para além decasos(sub)nacionaislocalizadose entram no terreno dosfenômenos globais.

D e vários lados, torna-se impossível reiterar diagnósticos e prognósticos tradicionais das ciências sociais para os quais a secularização moderna, a sofisticação tecnológica, o individualismo e a cultura de massas levariam a um progressivo declínio das práticas religiosas e da presença pública das religiões ${ }^{1}$. 0 que se percebe hoje é, primeiro, que a secularização não é um processo uniformee unilinear onde ocorre; segundo, que uma parcela muito pequena do mundo poderia ser adequadamente compreendida àluz des- 
sa representação da estrutura e dos efeitos da modernização; terceiro, avanços na secularização claramente em curso em várias esferas não apenas coexistem com avanços na adesão ou práticas religiosas, mas também rivalizam e reforçam-se mutuamente entre si (cf. Casanova, 1994; Pierucci, 1997; H ervieu-Léger, 1997²).

A prática mais corrente, fora dos países do capitalismo avançado ocidental, foi a de diferentes modalidades de hibridização da modernidade ou o surgimento de outras vias de modernização distintas daquela experimentada pelo 0 cidente rico. Pode-se dizer ainda que nem mesmo nessa parte do mundo houve um único modelo ou caminho de desenvolvimento histórico da modernidade. Se praticamente nenhum fragmento das sociedades existentes no planeta conseguiu subtrair-se de forma inteira e bemsucedida à mundialização do capitalismo e da modernidade, a multiplicidade decaminhos deixou, em grande parte dos casos, uma marca indisfarçável: a vitalidade das práticas, das organizações e dos movimentos religiosos, em graus variados (e somente analisáveis contextual mente), e sua capacidade de responder, reagir, reafirmar-se e negociar seus espaços na ordem moderna (cf. Casanova, 1994; Bingemer, 1998; Giumbelli, 2002; Burity, 2007a; M allimaci, 2008).

$M$ ais do que uma sobrevivência pré-moderna crescentemente circunscrita aos bolsões de atraso, miséria e tradicionalismo sociocultural do mundo, temos assistido nos últimos anos a um crescente "avanço" de movimentos e situações envolvendo atores religiosos (ou atores sociais e políticos para os quais sua identidade religiosa é ou tornou-se um componente especialmente relevante) nos países centrais. Em decorrência da migração (nem sempre recente, mas que adquire uma nova configuração com a emergência dos discursos multiculturais), dos ecos remotos ou das intervenções diretas de grupos e incidentes religiosos em países como Estados U nidos, Reino U nido, França, Alemanha, Austrália, "a" religião "volta" a fazer parte do cotidiano cultural e político. $H$ á ainda uma emergência global da religião, seja na forma de um espectro aterrorizante, um "totalmente outro" - o islã (erroneamente confundido com o radicalismo político islâmico) - , seja na forma de esforços de agregação macroecumênicos em defesa de temas caros às principais religiões do mundo (paz, justiça, comunidade, solidariedade etc.).

Articulando ou deixando-secruzar por questões deetnicidade, identidade nacional/racial/de gênero/etária, classe social e reivindicações políticas, essa contemporaneidade dos fenômenos religiosos, apesar do tom dramáti-
2. Estou ciente de que tais autores não convergem em detal hesemesmo em pontos importantes de suas análises. Apresento-os como indicação de que a afirmação queremetea eles não depende de um único marco analítico para ser aceita. 
3. Para uma discussão no campo das políticas sociais no Brasil, ver Burity (2006c, 2007b); M achado (2005). co e por vezes apocalíptico com que édescrita, encontra numerosas formas de expressão eacomodação menos espetaculares, pela via do envolvimento nas instituições representativas, nos formatos institucionalizados de participação popular (conselhos, câmaras, conferências, fóruns) eem distintas redes da sociedadecivil. N o processo, vão surgindo "reconhecimentos", "valorizações" e "diálogos" entre atores laicos e religiosos, não somente na effera nacional (e subnacional) como também no plano internacional eglobal ${ }^{3}$. 0 rganismos multilaterais e bilaterais, uma certa "sociedade civil global" de crescente importância, vão abrindo espaço a novas formas de conversação com os atores religiosos, enquanto no âmbito nacional e local as políticas públicas e a militância social vão se abrindo a formas de participação e legitimação desse segmento.

A impossibilidade de agrupar de forma indiferenciada o conjunto do que chamamos de "atores religiosos" num único campo e sob uma única caracterização soma-se ao quadro que sucintamente descrevemos, demandando diferenciações, qualificações e contextualizações importantes. Os exemplos contemporâneos são inúmeros. Para mencionar apenas al guns há pouco divulgados na mídia ou facilmente encontráveis na web:

a) Q uestão do islã e da violência religiosa (avanço do islã no 0 cidente desenvolvido, supostos conflitos civilizacionais entre 0 islã e o 0 cidente, inúmeros casos de violência política e cotidiana em várias partes do mundo, nos quais a religiosidade é uma variável relevante, quando não 0 elemento crucial).

b) D ebates sobre questões biopolíticas (políticas do corpo, gênero, sexualidade, reprodução humana, manipulação genética de organismos vivos, uso de recursos naturais).

c) Participação política e nas políticas públicas (processos eleitorais, representação parlamentar, escândalos políticos, participação de pessoas e organizações religiosas em programas e projetos sociais, arranjos multiculturais para acomodar a diferença [étnico-] religiosa, redes de atores da sociedade civil e movimentos sociais).

d) Acesso e uso da mídia (posse ou uso intensivo de canais e redes de tele e radiotransmissão, midiatização da linguagem religiosa por igrejas e grupos religiosos, presença das religiões na internet).

e) popularidade de temáticas religiosas (sucesso e polêmicas em torno do livro e filme 0 código $\mathrm{D}$ a Vinci, sucessos editoriais de literatura $\mathrm{N}$ ew Age e de auto-ajuda, e biografias de lideranças religiosas). 
No Brasil, os efeitos patentes de um processo de pluralização cultural vêm de par com a emergência de um campo das religiões (no plural), minando o monopólio católico-romano, mas ainda mantendo um monopólio cristão (se nos ativermos aos números apenas!) sobre a representação da adesão religiosa e da "matriz cultural" nacional (cf. Sanchis, 2001; Burity, 2005b, 2006c; Bittencourt Filho, 2003). Aqui, pode-se dizer que o reconhecimento pelas ciências sociais do processo em curso foi relativamente tardio, uma vez que o principal vetor deste processo no campo estrito das religiões, o protestantismo pentecostal, já vinha em acelerado processo de crescimento há várias décadas, o que no entanto era eclipsado pela hege monia do protestantismo histórico, pelo foco nas questões de desenvolvimento e da luta contra a ditadura, e pelo perfil radicalmente privado do ethos e da pregação pentecostais.

Tudo isso mudou radicalmente, por razões que não podemos detalhar aqui, a partir demeados dosanos de 1980, começando, no caso brasileiro, pela política eleitoral - a emergência de uma “bancada evangélica” na Constituinte trouxeà luz, decorpo inteiro, o perfil deum novo ator social: ospentecostais". D esdeentão, um quadro ainda maismultifacetado tem surgido à consideração das ciências sociais da religião e crescentemente o cenário internacional se povoa de referências que não passam despercebidas dos atores locais nem dos analistasacadêmicos. É o impacto dosfluxos globaistambém nesta área do social, produzindo efeitos-demonstração, diálogos e hibridizações ou reações quetecem umamalha intrincada nos planos cultural epolítico. N essesentido, poderíamos dizer que, à exceção do item "a" acima citado, todos os demais exemplos possuem sua correspondência no contexto brasileiro.

A desenvoltura da atuação de grupos e organizações religiosas na contemporaneidade tem suscitado vários desafios, dúvidas e perplexidades. Percebe-se que: a) há uma interação de mão dupla entre governos e organizações religiosas na implementação de programas sociais ou a representação destas últimas em diversos conselhos temáticos ou de políticas em todos os níveis - federal, estadual e municipal; b) há múltiplas interfaces entre organizações religiosas e outras organizações da sociedade civil (incluindo O N Gs, associações locais, sindicatos), em que o tema da religião entra pela via do reconhecimento e respeito à "diversidade" ou de uma miríade de parcerias pontuais ou abrangentes nos projetos de ambos os tipos de entidade; c) não apenas a religião, enquanto traço cultural eidentitário, aparece como um caso a mais dessas expressões da "diversidade" ou das demandas feitas em nome de identidades particulares, como também
4. A respeito do período e das mudanças e polêmicas observadas, ver, entre outros, Pierucci (1997); Pierucci e Prandi (1996); Freston (1993, 2004, pp. 11-56); Giumbelli (2002); M achado e M ariz (1999); O ro (2003); Burity (1994, 1997); Burity eM achado (2006). 
ela mesma - nessa esfera específica da "sociedade civil eclesial" - incorpora várias das questões quea sensi bilidade cultural envolve (por exemplo, gênero, raça e ambientalismo); d) não é difícil encontrar atores religiosos (pessoas eorganizações) em muitas redes e articulações da sociedade civil, local, nacional e globalmente (por exemplo, desde uma rede regional como a Articulação do Semi-Árido, quetem uma O N G evangélica em Recife como forte protagonista - e que sediava, até recentemente, a rede -, à participação de numerosas entidades paraeclesiásticas e ecumênicas nos Fóruns Sociais M undiais realizados, passando por redes de entidades em defesa de temáticas como direitos humanos, comércio justo, contestação do sistema financeiro internacional etc.). Assim, a articulação entre redes, cultura e religião não é artificial, e as interfaces entre esses temas/campos de ação social e as novas práticas governamentais com ênfase nas parcerias, na pluralidade e na "participação da sociedade" são parte integrante do cenário desde meados da década de 1990.

$\mathrm{N}$ a última década deu-se uma abertura de atores seculares (inclusive governamentais) para articulações e parcerias com atores religiosos (de múltiplos perfis, dos mais conservadores aos mais liberais [culturalmente] ou de esquerda [politicamente]). I sso pode ser compreendido no contexto dos questionamentos sobre em que medida vem se dando a sensibilização para questões edemandas culturaisno contexto das políticas edos projetos sociais (governamentais enão-governamentais) e como o campo religioso éao mesmo tempo afetado pelas eparticipanteativo das mudançasaí experimentadas. Assim, minha hipótese tem sido a de que houve efeitos do que no campo acadêmico se chama de "guinada cultural" no nível da dinâmica e das lutas sociais. Esse efeito tem a ver com a emergência da temática cultural como objeto de debate público e político ecomo elemento nucleador deformas de ação coletiva. Políticas de identidade, multiculturalismo, ações afirmativas, políticas da cultura, diversidade cultural e pluralismo, diversidade cultural e consumo (turismo, lazer, políticas culturais), novos movimentos sociais, ampliação da política, redes são al gumas das referências que compõem o quadro de uma contemporaneidade da qual a religião é parte inseparável, independentemente da avaliação que façamos disso (e há várias em disputa). As perguntas sobre o que está acontecendo e para onde deveríamos ir (ou como nos posicionarmos diante do que acontece) são parte dessa análise.

Tal contexto de internalização da diferença religiosa, numa sociedade pouco afeita à livre manifestação da diferença cultural e do dissenso político, não tem se dado sem ansiedades e tensões. Como o mito da fundação 
republicana, em seus ecos histórico-normativos provindos das experiências francesa e norte-americana (as de maior influência no caso brasileiro), demarcava claramente um limite para a movimentação religiosa no espaço público das instituições, as tendências atuais parecem conflitar com as aspirações de realização do modelo. $E$, no entanto, nunca se falou tanto em republicanismo como solução para os males nacionais. A luta pelo aprofundamento da democracia nas últimas décadas tem reposto um certo número de bandeiras republicanistas com a intenção de ampliar e assegurar a existência de um espaço público livre deinterferências arbitrárias dos poderes privados, da corrupção, da apropriação privada do Estado e, na conjuntura neo e pós-neoliberal, com força suficiente para impor o interesse público aos interesses do mercado. 0 corre que esse discurso republicano afirma-se em meio a umajá ampla penetração dos discursos diferencialistas, para os quais não épossível conceber democracia sem pleno reconhecimento da pluralidade constitutiva do social (expressa não só tem termos de diversidade, mas também da existência de projetos e concepções do bem em disputa, seja em efferas sociais restritas, seja pela hegemonia da formação social como um todo). N esse contexto, a tentativa de construir uma síntese entre cidadania republicana e cidadania diferenciada suscita problemas de não pouca monta, pois ambas correm a contrapelo da experiência política brasileira pós-República 5 .

Como isso rebate sobre a questão da agência religiosa na conjuntura atual? Bem, primeiramente, em nome do republicanismo, reacende-se a desconfiança de que a presença religiosa na esfera pública a enfraquece, pois introduz uma lógica particularista no lugar onde só deveria prevalecer o interesse de toda a sociedade. Segundo, tal presença agrediria um pilar do republicanismo, que é a laicidade do Estado. Terceiro, conceder espaço à mobilização organizada das religiões significaria reforçar os efeitos fragmentadores do diferencialismo (seja porque a pretensão de verdade do discurso religioso não combina com pluralismo e respeito à diferença, seja porque isso abriria a porta a que um número indefinido de demandas por representação e reconhecimento enfraquecesse os acordos coletivos substantivos necessários à preservação de uma ordem democrática). Q uarto, o conservadorismo moral e político convencionalmente associado aos atores religiosos reforça a imagem de indesejabilidade de admitir ou promover essa participação na effera pública - ela jogaria água ao moinho da direita política no momento mesmo em que estaria mobilizando novos contingentes sociais para atuarem politicamente 6 .
5. Alguns exemplos de análises, diagnósticose propostas republicanis tas ancoradas na experiênciabrasileira podem ser encontrados em Bignotto (2000); C ardoso (2004); Starling (2003); Segato (2007); Birman eLeite (2004).

6. Ver al gumas matérias de jornal recentes em que argumentos semeIhantes são apresentados (Sardinha, 2007; Ferrare, 2007; Garcia, 2005; M endes, 2008; Fischmann, 2007; Abaixo-assinado, 2007; Ensino, 2008). Alguns argumentos acadêmicossobrelaicidade, efeitos e questionamentos dapresença religiosana esfera pública no Brasil podem ser encontrados em Lorea (2008); Batista e M aia (2006); Castilhos (2007). 
A conjunção entre as repetidas revelações de situações de corrupção política em todas as esferas de poder no país - em todos os poderes, em todos os níveis da federação - e o envolvimento de grande número de políticos religiosos reforça a percepção de quea pregação republicanista precisa recuperar as clássicas teses sobre a evacuação da religião da esfera pública. Afinal, se sequer um efeito moralizante ela pode inequivocamente exercer, que se dirá dos seus efeitos heterônomos sobre a liberdade e a autonomia dos cidadãos?

Pelo curso dos acontecimentos, as resistências, as desconfianças eas oposições à aproximação entre instituições e políticas públicas e organizações ou demandas religiosas não têm sido capazes de neutralizar o duplo movimento de mobilização organizada de grupos religiosos e sua confluência com o processo de legitimação da cidadania diferenciada, com sua insistente defesa da pluralidade, da tolerância e do reconhecimento das minorias. $N$ aturalmente, o processo é ambíguo, apenas em contextos concretos se pode discernir seu caráter conservador, reacionário, progressista ou radical; democrático ou autoritário; tolerante ou intolerante. E assim progride rizomaticamente a participação de atores religiosos no espaço laico da política e das ações governamentais. Como diz Tariq M odood, a partir do caso britânico da ascendente presença muçulmana na esfera pública,

[...] a política do reconhecimento pode ser desenvolvida mais além, para enfatizar que há um ideal de igualdade emergente que repudia a necessidade de privatizar toda diferença em nome de uma igualdade cívico-republicana formal. A igualdadeé interpretada como equilibrando o poder sempre presente das identidades hegemônicas, geralmente disfarçado como universal, com o reconhecimento, até mesmo a celebração, público(a), de identidades marginais ou suprimidas (2005a, p. 18).

Ver é tomar posição

Tal caracterização do cenário é, claramente, mais do que uma descrição. $\mathrm{N}$ ão escondo que tudo acima está informado por um quadro interpretativo. Poderia ser diferente? $\mathrm{N}$ o veio das ciências sociais críticas, de há muito abandonou-se a pretensão de que a objetividade científica se constrói pela ou resulta na ausência de referenciais teóricos, morais, políticos e históricos. Em suma, a objetividade é sempre contestada, sendo mais o efeito de lutas do que a mera fotografia do que "está aí" para qualquer pessoa ver. 0 bviamente, ninguém em sã consciência se afirmará como nada preten- 
dendo ao descrever, analisar, senão 0 alcance da sublimidade do saber. $\mathrm{N}$ em mesmo se acredita mais que a busca da verdade se refira a um objeto monolítico ou atemporal ${ }^{7}$. Assim, de um lado a caracterização pretende poder dizer algo significativo sobre o mundo, ao mesmo tempo em que fazêlo implica delimitar, polemizar ou mesmo confrontar outras caracterizações.

Ver, assim, é tomar posição, duplamente: a) vêse a partir de uma posição, escolhendo-se os ângulos que se julga melhores, ou espreitando-se por entre os limites colocados pelas circunstâncias; b) não se vê desinteressada mas ativamente, o que quer dizer que não se pode ver tudo de uma vez (é duvidoso mesmo saber qual éo "tudo" quehá para ver senão ex-post), nem se deixa de contrair vínculos - de amizade, de antagonismo, de indiferença em relação ao que se vê. N unca se vêtudo. Além disso, nunca vemos sozinhos- mesmo quando fisicamente sós. Vemosjunto com outros ena proximidade ou distância de outros, o que dividenosso ol har entre o quevemose o que se nos dá a ver pela presença (próxima ou distante) do outro.

Tenho tentado, assim, delimitar minhas visadas ao tema da religião na contemporaneidade a partir de um eixo que me parece estar fortemente radicado no espectro de questões da ciência política ${ }^{8}$, grosso modo agrupadas sob o tema "religião e política". Agora, ao enfrentar as questões suscitadas por tais processos, tenho-o feito por meio de: a) uma rediscussão do caráter e do lugar do político na sociedade contemporânea e as repercussões disso para a questão da religião; b) uma recepção do debate sobre o pluralismo, como referencial analítico ao mesmo tempo político, social e cultural, e como base epistemológica para a compreen são das sociedades contemporâneas (enão somente seus sistemas políticos); c) uma abertura da linguagem e das práticas de análise da ciência política para as contribuições vindas da sociologia, da antropologia, da filosofia e dos estudos culturais como proposta inter ou transdisciplinar; d) um conjunto de "incursões" em diferentes territórios para aí perceber as transformações da relação entre religião e política - movimentos e partidos de esquerda, movimentos sociais e outras formas deação coletiva, cultura eidentidade, cultura política, teoria política democrática, epistemologia da pesquisa sobre religião, mídia, reforma do Estado, políticas sociais (cf., por exemplo, Burity, 1994, 1998, 2000, 2001a, 2002a, 2002b, 2006b, 2006c).

Esse esforço tem como sentido abrir um campo de questionamentos e interrogações, com contribui ções empíricas ilustrativas e exploratórias (mais do que sistemáticas), e resistir ao acantonamento dos estudos da religião em uma subdisciplina da sociologia/antropologia ${ }^{9}$ ou entre os profissionais das
7. C laro, épreciso dizer quehámuitosqueassim o fazem. C rêem na verdade, nainjunção à verdade ena possibilidade de alcançar a verdade. $M$ as todos estes, ainda queem poucosmomentosvenhamapermitir-se questionar motivoserealizações, poderiam honestamenteassumir que não possuem a verdade quealmejam (ou defendem - estando ela sempreà mercêdos ataques dos de fora ou desvios dos de dentro), ou não conseguem dar contade tudo à sua volta com a verdade de que já dispõem.

8. M as para o qual a maior parte da ciência política brasileira, desde o período pós-transição, tem dado escassa atenção ou reproduzido apreciações e argumentos no mínimo convencionais ou anacrônicos.

\section{A ciência política} nunca chegou a constituir o estudo da religião numa subdisciplina, como o fizeram a sociologia e a antropologia, chegando no máximo a consolidar uma área de investigação guarda-chuva sob o rótulo de "religião e política". 
10. Estou consciente de usar este termo num sentido generoso, mesmo sabendo queal guns dos objetos com que os cientistas sociais se defrontam (ou com que constroem) transbordam crescentemente as referênciasdisciplinares, resistindo mesmo a abordagens "inter" e sinalizando com a necessidade de estratégias "trans" - e"pós" - disciplinares. Paranão entrar num debate epistemológico queextrapolaem muito os limites de um projeto depesquisa, usamos simplesmente "interdisciplinar" para dar contadessecampo deestratégiasintelectuaisque "desliza" entreasfronteiras disciplinares ou as "agride" a partir deestratégias de pesquisa problem-driven.

11. Parece-me que, mesmo admitindo-sea noção de "caso", tratasecada vez mais dealgo quese dá em escalaglobal, enão apenas como expressão de particularismos nacionais ou regionais, a serem estudados ao modo das exceções ou sobrevivências.

12. M uito sucintamente, esta concepção teria três conseqüências: a) uma concepção não-es- ciências sociais da religião, mantendo um diálogo aberto e, até certo ponto, provocativo com o mainstream das ciências sociais (inclusive as aplicadas, notadamente a área de administração pública) e humanas, informado por uma postura explicitamente interdisciplinar ${ }^{10}$. A aposta desse esforço tem sido a de que assim é possível ressaltar a relevância dos processos e dos fenômenos religiosos para a compreensão das transformações vividas pelas sociedades contemporâneas, e não apenas, embora também, como um caso destas" ${ }^{11}$. Assim, esse campo pode surgir como uma espécie de "laboratório" para "testar" novas teorias sociais e políticas desenvolvidas nas últimas três décadas.

Tal modo de enquadrar a relação entre religião e política não deve ser pensado como um exercício de dispersão sem limite. N o caso da presente análise, a aparente dispersão está enfeixada por al guns operadores teóricotemáticos: teoricamente, uma reflexão sobre o político como ontologia social (enão como uma região, nível ou esfera delimitada), àluz de uma interrogação vinda da teoria política de orientação pós-estruturalista12; uma tentativa de construir (a partir de investigações empiricamente inspiradas) uma abordagem contemporânea da relação entre religião e política; e uma reflexão sobre as transformações do campo democrático a partir das questões da cultura e da identidade (coletiva). Empiricamente, meu trabalho tem revolvido sobre questões de participação e militância social - movimentos sociais, sociedade civil, formatos participativos nas políticas públicas, representação política, cultura, identidade e mídia.

O s desafios, as dúvidas e as perplexidades da seção anterior, se não bastasse referirem-se ao contexto mais amplo em que as relações entre Estado, sociedade civil e mercado se transformam, atravessadas pelos processos de globalização, também são agudamente postos no caso da presença pública das religiões. Q ue mudanças é preciso introduzir ou admitir para dar conta dessa presença? Seria o caso de reafirmar as clássicas teses secularistas ${ }^{13}$ sobre a separação entre I greja e Estado, traduzindo-as em termos ainda mais rigorosos, como separação entre religião e política? M as se trata ainda apenas de "igreja”? E há uma só "religião" relacionada com a política? N ão é preciso admitir a capilaridade das religiões no cotidiano e nos espaços onde se concentram as desi gual dades e as exclusões acumuladas ou intensificadas pela nova ordem econômica neoliberal, provendo anteparos e recursos simbólicos aos perdedores, atuando onde o Estado não se faz presente e mesmo como parcei ras deste? Por outro lado, essas parcerias não repõem o focalismo, a filantropia e a despolitização nas medidas de provisão social, reforçando a 
desresponsabilização do Estado por estas? As identidades religiosas não possuem a quase irresistível tendência de acirrar paixões e desencadear intolerâncias e violência? A fragmentação da effera pública entre múltiplas identidades reclamando espaço, autonomias e bens públicos não estaria levando a democracia a um enfraquecimento por tornar-se excessivamente complexa, abrigando e legitimando lógicas contraditórias? N ão é patente que são quase sempre os setores mais tradicionalistas das religiões que se beneficiam dos arranjos multiculturais, o que produz efeitos de retardo ou barreira às lutas emancipatórias? Enfim, há uma agenda de questionamentos para os quais não há respostas curtas e simples.

A meu ver o contexto delineado suscita três conjuntos de problemas que pedem novos estudos e posicionamentos. Primeiro, é preciso tentar ir além das referências nacional e local, segundo um entendimento de que o nexo global/local redefine de modo instável as fronteiras e a "jurisdição" de ambos (cf. Santos, 2002; Santos e N unes, 2003; Scherer-Warren, 1999; Costa, 2003). A unidade de análise das ciências sociais (a sociedade nacional) precisa ser deslocada numa direção pós-nacional. Isto, por sua vez, não significa nem abandonar a importância da referência nacional, nem proje tar um megaprocesso societário que viria "de fora" e "de cima", impondo-se irresistivelmente. Trata-se de assumir as conseqüências de que os processos locais e nacionais hoje se dão de forma cruzada com processos globais e, mesmo quando a análise recorta os espaços e os tempos da local idade ou da nação, não pode perder de vista os inúmeros vínculos que esses contextos mantêm com fluxos, forças e processos que vão além deles ${ }^{14}$.

Em segundo lugar, a questão não é mais, pelo menos num futuro próximo, se "a religião" deve estar presente na esfera e nas instituições públicas, mas como dar sentido a esta presença, como perceber suas diferentes modalidades, impactos e fontes ${ }^{15}$ e como avaliar as distintas implicações das relações entre esses atores (e mesmo projetos) religiosos e seus interlocutores e adversários não-religiosos. Entre estes dois campos, não se trata simplesmente de posições nitidamente demarcadas, mas de duas referências contingentes, as quais podem ser ocupadas de forma híbrida ou heterogê nea de ambos os lados, dependendo da questão (issue) ou conflito que de fine as fronteiras.

Em terceiro lugar, é necessário inscrever a diferença religiosa num contexto mais amplo da conflitividade contemporânea, em que cultura e identidade ${ }^{16}$ se articulam com religião, democracia e republicanismo (para nos mantermos no limite do debate até aqui evocado e demarcado). Isso significa, de sencialista, contextualista e pluralista da realidade social e do conhecimento; b) uma compreensão de que o político é uma dimensão instituintedavidasocial, podendo emergir em qualquer "lugar" desta, informando diferentes práticas sociais, para além do conjunto de instituições e práticas convencionalmente chamadas de políticas; c) uma preocupação em identificar lugares, atores e práticas que sina lizariam aemergência de novas formas sociais (descritivamente- sinalizando a dinâmica social, mesmo que esta aponte para direções conservadoras ou regressivas- enormativamente - esforçando-se por identificar e dar visibilidadea experiências de caráter emancipatório). Asprincipaisreferências desta elaboração estão no trabalho de autores como Ernesto Laclau, Chantal M ouffe, Stuart $\mathrm{H}$ all, Jacques Derrida, JacquesRancière, Alberto M elucci, Boaventura Santos, entre outros.

13. U so o termo "secularista" neste projeto para nomear aquelas correntesque propõem um radical esvaziamen- 
to dasesferaspúblicasde qualquer componente de linguagem e autoridade religiosas. Ver a respeito a análise crítica deConnolly (1999). U m evento realizado em maio de 2007 na Universidade de Copenhague reuniu pesquisadores de vários países para discutir o tema "Secularism and Beyond ComparativePerspectives" (cf. http://www.ku. $\mathrm{dk} /$ satsning/religion/ sekularism_and_beyond/ index.asp).

14. M as a direção desses vetores não vai somente do nacional/local ao global. Este não existe sem relação com o nacional/local, sendo afetado, especificado e transformado por sua realização em nível local (cf. Burity, 2008)

15. Aqui será cada vez maisinevitável explorar asconseqüênciasdapluralização do campo das religiões, para além do cristianismo dominante nos países ocidentais, como o Brasil. Isso não decorreapenasdapluralidade de religiões existentes neste país - que afinal não étão significativa ainda do ponto de vistadasuadispersão demográfica -, mas dos um lado, pensar a religião como parte da emergência da dimensão cultural como objeto de análise e de lutas e conflitos sociais - remetendo-nos a debates sobre (in)tolerância; pluralismo; fundamentalismo; diálogo intercultural, ecumênico e inter-religioso; demandas identitárias; secularização/ ressacralização; cidadania multicultural; afirmações étnicas e raciais; construção de culturas políticas democráticas. De outro lado, tal orientação significa interrogar-se sobre a necessidade e a experiência concreta de "acomodação", "reconhecimento", "regulação" das diferenças culturais (e religiosas) por parte da ordem democrática em intenso processo de transformação. 0 contexto é de um "equilíbrio catastrófico" (Gramsci) entre a regressão a componentes autoritários e particularistas como parte da definição e da prática democrática e o aprofundamento de noções de direitos, cidadania e participação que radicalizam a democracia pelo fortal ecimento de sua(s) esfera(s) pública(s).

N esse marco, é possí vel dizer que as reli gi ões e as diferenças religi osas são um elemento ativo e inseparável das dinâmicas culturais e políticas que estão transformando o sentido do vínculo social e do político em nosso tempo, quer quando se expressam de forma regressiva, quer emancipatória. U ma conseqüência imediata do enfoque esboçado acima é a de que é preciso analisar deforma comparativa algumastraj etóriascontemporâneas da religião. A preocupação central aqui é com o impacto do contexto global e dosnovos debates sobre inclusão, igualdade e diferença ${ }^{17}$ nas relações entre religião e política - impacto empírico, sobre processos eatores, eimpacto analítico, sobre esse campo de estudos. É o momento não só de colocar o Brasil em perspectiva comparada, de modo a perceber como nosso "experimento nacional" incorpora, replica, seleciona e adapta o que vem "de fora", mas também inventa - bem e mal - alternativas ou atalhos. É o momento deperceber a pluralidade irredutível de caminhos, e o lugar nelas das práticas religiosas, que tais dinâmicas culturais e políticas definem temporal e espacialmente. É o momento de perceber, no nervosismo com que os establishments político e cultural se vêem em face da retórica pouco polida e politicamente incorreta das identidades religiosas emergentes, não somente posições normativas confrontando-se com outras, mas também alianças sendo forjadas com setores e franjas de ambos os campos (atores estabelecidos e minorias religiosas), em busca de hegemonizarem o discurso institucional e/ou cultural sobre as relações entre política e religião. Em outras palavras, vemos a estratégia comparativa como forma de salientar práticas hegemônicas em operação: ora podendo relativizar posturas locais apresentadas como uni- 
versais, ora podendo ressaltar a iterabilidade - segundo $D$ errida, a repetição/alteração de modelos ou elementos de um contexto em outro(s) - de posturas apresentadas ou percebidas como apenas locais.

N o plano internacional, as reflexões sobre o lugar da religião têm apontado para três grandes conjuntos de debates:

a) D emocracia e republicanismo: a admissão de que os movimentos religiosos e demandas por reconhecimento de identidades particulares, entre as quais e no interior das quais emergem as religiosas, são legítimas expressões da pluralidade e/ou da heterogeneidade das identidades nacionais outrora pensadas nas chaves uniformizadoras de uma cultura ou da cidadania política (cf. M ouffe, 1992; Kymlicka, 1998, 2000; M odood, 1998, 2005a, 2005b; Davidson, 1999; Parker G., 1999; Jennings, 2000; Shachar, 2000; Fraser, 2001; Lupu eTuttle, 2002; Lara, 2002; H all, 2003; $\mathrm{H}$ abermas, 2004; Burity, 2005b; Gruman, 2005).

b) Religião e políticas públicas: a implementação de procedimentos e instituições que operacionalizem essa resposta a pressões por inclusão multicultural tem ensejado a ocupação de espaços na esfera pública por parte de atores religiosos de várias orientações ético-políticas, dos mais reacionários e dogmáticos aos mais liberais e ecumênicos. N ovos atores religiosos têm ampliado sua presença no nível da representação política, como parlamentares ou governantes, eno nível da governança, como parceiros de políticas públicas ou representantes da sociedade civil em conselhos, conferências e fóruns (cf. Ammerman, 1997; Cobb J r., 2001; C haves, 2001; Kennedy e Bielefeld, 2002; Parekh, 2002; Cochran e Cochran, 2003; Richardson, 2003; H eclo eM cClay, 2003; Beckford eGilliat, 2005; Landim, 1998; Burity, 2003a, 2007a; Birman, 2003, 2004; Conrado, 2005; Q uiroga et al., 2005).

c) Religião e gl obalização: há quase duas décadas vários autores passaram a insistir na emergência da religião como força social e política no cenário global (cf. Swatos) r., 1989; Robertson, 1989). N os últimos anos tem-se tornado patente tanto a crescente visibilidade desses atores no cenário global (e não só a partir de referências nacionais e locais) como a dispersão das formas de intervenção nesse contexto, embora, se se tomar a dimensão mais midiatizada delas, prevaleçam as formas conservadoras (cf. Burity, 2001a; Roof, 1991; Casanova, 1994; Beyer, 1994; O ro e Steil, 1997; H aynes, 1998; Berger, 1999; Scherer-Warren, 1999; Riesenbrodt, 2000; Esposito eWatson, 2000; Vasquez et al., 2001; O r- vínculos, das ressonânciasedasimplicaçõesde outros cenários religiososno plano global, que reajustam percepções, posicionamentosevalores de diferentes atores sociais, mesmo distantes dos centros de gravitação daqueles cenários.

16. Termos contestados, mas ainda úteis para nomear um conjunto deoperaçõesanalíticas e sociopolíticas que nos dão preciosas chavesdecompreensão e posicionamento do/ no mundo em quevive mos.

17. Três deles poderiam ser citados- multiculturalismo, ações afirmativasepolíticaspúblicasem que a natureza dos issuesdesperta a atenção de ou incidem diretamentesobreáreasdetra dicional preocupação do pensamento religioso:questõesdeliberdade depensamento, expres são ecrença- incluindo censura e uso da/acesso à mídia; relação religiões/Estado (representação política e marcos legais); sexualidadeereprodução; família; bioengenharia; pobreza; direitoshumanos; violência. A aparentedispersão dessestemasrevela-sena verdade cada vez mais 
atravessada por numerososvínculoscruzados, tanto no nível do discurso como das redes de atores envolvidos, tornando a análisecientífico-social desses processos complexa e demandando um aporteinterdisciplinar. tiz, 2001; Koshy, 2002; Freston, 2004; Turner, 2006; G urney, H adsell e Mudge, 2006).

Essas questões têm entrado de modo desigual nos debates público e acadêmico brasileiros. Sobressai um contencioso que tem muito a ver com a notoriedade da emergência evangélica na política institucional (eleições e atuação lobista ou por meio de mecanismos estatais institucionalizados de representação social) e as controvérsias que tem suscitado. A despeito do peso exercido historicamente pelo catolicismo na delimitação das relações religião/Estado, as características do debate público apontam mais para o silêncio e a condescendência do que para a resistência aberta (cf. Burity, 2005a, 2006b, 2006c); são poucos os casos em que uma discussão é publicamente sustentada por algum tempo, sendo uma exceção a controvérsia sobre o "chute na santa", em 1995 (cf. Giumbelli, 2002). Por outro lado, deu-se uma visível diminuição da atenção aos desenvolvimentos católicos fora das constatações de sua crise e uma inflação de estudos sobre os pentecostais. M as no nível mais informal das conversas em eventos acadêmicos ou de entrevistas com atores sociais religiosos e seculares, percebe-se uma preocupação com os desdobramentos do processo de rearrumação em curso no campo religioso brasileiro, para a integridade democrática do espaço público, dadas a frouxidão com que o marco institucional regula a atividade pública das religiões e a tendência do discurso religioso à intolerância (cf. Birman, 2003; Burity, 2006c; Freston, 2004; Freire-M edeiros e C hinelli, 2003).

0 foco sobre a atuação político-eleitoral dos evangélicos tem de certa forma eclipsado seja a continuidade, seja a emergência de outros processos nos âmbitos da "sociedade civil eclesial" e da relação entre sociedade civil, Estado emercado, nos quais épossível divisar uma tentativa deorganizações religiosas confrontarem os problemas postos pela questão da diversidade cultural, da partici pação democrática e das transformações do Estado e do governo; construírem redes e articulações com organizações laicas da sociedade civil, em escala transnacional e local; e redefinirem suas identidades num diálogo difícil com a cultura ea esfera pública brasileiras.

No campo internacional, há numerosas referências de organizações paraeclesiásticas ou "não-governamentais religiosas" que têm atuado com força na área do ativismo social e das políticas públicas, de forma moderada ou claramente no campo da esquerda (cf. Chandler, 2000; Dionne Jr. e Chen, 2001; Angrosino, 2003; Chaves, 2001). Essas experiências ajudam a 
recolocar na agenda processos aparentemente latentes de (re)negociação de espaços e identidades entre atores religiosos e laicos na esfera pública. No ativismo da sociedade civil e na fronteira entre esta última e as práticas governamentais encontram-se dois lugares privilegiados para analisar a conjuntura das relações explicitadas nos debates indicados.

Retomando o caso com que encerramos a seção anterior, al gumas implicações do argumento acima poderiam ser realçadas. Primeiro, os debates a respeito do impacto religioso sobre o caráter republicano das instituições, quando postos em perspectiva comparativa, revelam muitas confusões entre julgamentos de fato e de valor. $\mathrm{N}$ ão no sentido de que tais dimensões são inseparáveis em nossa experiência da objetividade do mundo a nossa volta, mas no sentido de que é freqüente o contrabando de interpretações ideal izadas e posições normativas inconfessas como se fossem constatações de processos dados para qualquer um ver. Nada demais, à vista do que assumimos neste argumento. 0 problema não éque fato e valor se confundam, é apresentar como fato o que nunca se deu ou se dá exatamente do jeito que se diz; é apresentar como dado o que na verdade é uma proposta, um projeto. Problema não para que lamentemos ou nos indignemos, mas para que assumamos que a ontologia social é uma construção política.

Assim, os arranjos historicamente reconstituíveis ou em operação no presente de relação entre religião e política são muito mais impuros, variáveise contingentes do que sua aparentevitalidade, solidez ou respeitabilidadehegemônicas revelam. Republicanismo, separação entre I greja e Estado, laicidade, pluralismo, multiculturalismo, democracia e atores religiosos, quando abordados sociológica e historicamente, enão filosófica ou ideologicamente, cruzam-se de muitas maneiras, e parte do debate suscitado em torno deles envolve as múltiplas articulações possíveis, testadas na prática ou imaginadas, entre tais construtos sociológicos e históricos.

$\mathrm{N}$ esse sentido, em certa medida, depende de em qual entre as tendências abertas no presente se vai apostar. O s atores sociais não raro apegam-se a evidências fragmentárias, duvidosas ou mesmo falsas, ou fabricadas, para projetarem propostas e demandas nos espaços públicos da cultura e da política. Q uem imaginaria, antes da Revolução de 0 utubro na Rússia, ou durante as ditaduras de Batista e Somoza, em Cuba e N icarágua, que uma teorização complexa como a de $\mathrm{M}$ arx e Engels se transformaria em energia vital de experiências anticapitalistas na periferia do mundo capitalista? Q uem pensaria, ainda, queuma teoria extremada como o neoliberalismo de um $\mathrm{H}$ ayek, originalmente articulada nos anos de 1940 e esposada por um 
punhado deintelectuais de direita em al guns países, poderia, por via deuma agência política deliberada e infensa a contra-evidências empíricas, tornarse uma força econômica, política e cultural mundial?

As articulações entre religião e política, quero sugerir, são mais complexas e indeterminadas do que muitas reconstituições historiográficas dos modelos republicanos fazem crer. É relativamentefácil a qualquer observador bem informado, participante ou não da retórica política dos grupos religiosos, posicioná-losno espectro político-ideológico esimpatizar ou não com eles. N o entanto, as possibilidades de composição, táticas ou substantivas, efêmeras ou duradouras, entre atores seculareseatores religiosos podem ser materializadas em direções insuspeitadas. Ainda mais se se aceitar, como propus, que o que ocorre no âmbito da religião se inscreve em contextos mais amplos de desenvolvimento de suas tendências contemporâneas: a da imbricação e hibridização das identidades (pessoais e col etivas) e a da constituição de comunidades que se mobilizam politicamente a partir de um conjunto limitado de características identitárias em nome de espaço e reconhecimento na esfera pública.

0 registro comparativo permite minimamente constatar que as democracias contemporâneas continuam a dar lugar à mobilização eorganização de forças religiosas (por exemplo, Estados U nidos, H olanda, Reino U nido, Alemanha, Itália, M éxico, Brasil), sem que isso represente um "excesso" de visibilidade e influência. A comparação também permite perceber que tal internalização da diferença religiosa decorre de fatores perfeitamente contemporâneos, como a imigração; a sistemática extensão da regulação estatal sobre efferas antes consideradas privadas (mesmo íntimas) da vida social e pessoal, por meio de políticas públicas ou de legislação (governamentalidade); a escalada da desigual dade e da exclusão e a intensificação e diversificação de formas de resistência que atravessam fronteiras nacionais; o impacto (aceito ou recusado) da penetração da lógica e das práticas de mercado em todas as dimensões da vida social (commodification); e o avanço das demandas por reconhecimento da pluralidade cultural na estrutura da representação política e nas arenas das políticas públicas (multiculturalismo).

N ão estamos, portanto, sós ou na contramão do mundo, nesse particular. 0 desafio da contemporaneidade nas relações entre religião e política não é reafirmar o modelo da separação I greja-Estado (a própria expressão torna-se cada vez mais caduca, ante a diferenciação do campo das religiões para além do cristianismo no 0 cidente) ou a neutralidade das instituições republicanas. É incorporar a conflitividade das lógicas culturais e, entre 
elas, religiosas, ao cotidiano dos debates públicos, do governo e da representação política. É desdramatizar essa presença no contexto de um republicanismo reconstruído, pluralista, agonístico e democrático, sobre o qual estamos em melhor companhia olhando ao redor e para a frente do que buscando reeditar model os que de fato são sínteses ex-post a partir de situações contingentes ${ }^{18}$. N inguém precisa gostar de ou aderir a qualquer religião nesse contexto para admiti-la como parceira ou adversária legítima. Aliás, mesmo as formas de adesão religiosa atuais são múltiplas. É no embate democrático agonístico que não apenas as diferentes posições religiosas, mas também a quali idade de sua contribuição, os limites de sua representatividade social e poder de interferência se definirão.

É novamente M odood que me permito citar longamente aqui, por sua eloqüência ao sintetizar:

As idéias de uma separação I greja-Estado e de que a religião e os grupos religiosos não deveriam ter um papel na política e nas disputas democráticas são, naturalmente, de uma forma ou de outra, extremamente populares, quase universal mente apoiadas por intelectuais não só nos Estados U nidos mas também na Europa 0 cidental e muitos outros lugares no mundo. São vistas por liberal-democratas, socialistas e republicanos como um dos pilares centrais de sua política, a tal ponto que são simplesmente dadas por óbvias e sem necessidade de discussão. [...] D e fato, 0 multiculturalismo dominante na teoria liberal afasta-se de R awls ao separar o domínio das identidades culturais entre religião e o resto, e favorece um reconhecimento explícito em relação, digamos, a línguas e costumes minoritários, mas 0 não-reconhecimento em relação areligiões minoritárias. Por exemplo, W ill Kymlicka argumenta que a estrita separação entre Estado e etnicidade, "o modelo da religião", é incoerente, mas contenta-se com o modelo de separação conquanto ele se aplique apenas à religião. [...]

A política do reconhecimento e posições feministas relacionadas têm demonstrado com sucesso os limites da separação público-privado necessária a que um Estado seja culturalmente neutro. Semelhante e controversamente, segue-se que o secularismo não pode ser neutro entre religiões. Isto é discutido com base em tipos ideais de Estado e as concepções do indivíduo e da comunidade que os informam, especificamente em relação ao Islã, ao secularismo europeu ocidental eà ligação I greja-Estado na Inglaterra. A presença de novas minorias religiosas implica que os compromissos constitucionais existentes, de um secularismo mode rado, precisam ser reformados no espírito da inclusividade e não da neutralidade. Quer dizer, é preciso considerar construtivamente como os arranjos existentes
18. U ma interessante discussão a respeito da necessidade de uma nova concepção da relação entrereligião erepublicanismo pode ser encontrada no diálogo entre $M$ aurizio Viroli e N orberto Bobbio sobre o temor a D eus eos de safios da república eda democracia (cf. Bobbio eViroli, 2007, pp. 5382). 
podem setornar mais plurais (2005a, pp. 19, 20; cf. Casanova, 1994, pp. 39, 58$62,211)$.

Concluo que, mais do que aferrar-se a uma afirmação dogmática da necessidade de um fosso institucional ou político-ideológico entre a lógica da religião e a do Estado laico, o contexto presente mantém abertas duas portas pelas quais, já se pode perceber, muitos - atores e analistas - vão entrando, pragmaticamente ou por convicção:

a) À medida que se consegue a adesão o mais geral possível dos cidadãos e dos atores coletivos à institucionalidade democrática e suas formas de discussão e deliberação públicas e de tomada de decisões, a presença de atores religiosos (ainda quando performatizada segundo a linguagem e os modos da cultura religiosa) não representa per se nenhuma ameaça que justifique uma lógica de premptive action nas relações entre religião e política; de um lado, o pluralismo da ordem democrática é compatível com posições de diferentes matizes político-ideológicos e ético-sociais, dependendo mesmo do conflito entre elas para manter-se aberta e passível de avanços (M ouffe); de outro lado, a contínua co-participação de atores sociais portadores de diferentes concepções do bem nos espaços públicos pode ter um efeito de inclusão e co-responsabilização pelos destinos da comunidade política, enão somente de enfraquecimento efragmentação dela. As grandes ameaças que já se mostram nas democracias contemporâneas têm a ver com sua despolitização (e, portanto, perda de sua dimensão agonística em favor de um gerencialismo generalizado e uma aversão ao dissenso e ao "risco") e o rebaixamento das exigências político-culturais de decência e seriedade com a coisa pública. D esses processos pode-se dizer no máximo que os novos atores religiosos são partícipes, não o fator desencadeador ou intensificador.

b) Não há uma única política a derivar de qualquer posição ética, filosófica ou ideológica, nem nenhum discurso, por mais hegemonizado que esteja numa direção, pode controlar total ou indefinidamente a circulação de seus significantes, afirmações e repertórios de ação associados; o quequer dizer que conservadorismo em religião pode rimar com posições políticas republicanas e democráticas, ou que liberalismo em religião pode combinar com posições políticas conservadoras e autoritárias. M as, também, que há várias convergências possíveis entre discursos críticos intrareligiosos e não-religiosos. A pluralidade de posições ético-políticas já é 
uma marca no campo das religiões e hoje elas disputam sua hegemonia tanto dentro como fora dos espaçosinstitucional izados das religiões, como são também identificadas e interpeladas por forças não-religiosas enquanto aliadas, parceiras e possíveis novas bases sociais de apoio.

A posição queexponho não deveser absolutamenteconfundidacom ade uma defesa relativista do igual val or entre posições diante da inegociabilidade do caráter laico do Estado e da primazia do interesse público sobre posições particularistas (em especial as que pretendem impor-se à aceitação das demais ou contra as demais, em nome de sua especificidade ou de sua superioridade). $\mathrm{N}$ em todas as posi ções são igual mente válidas ou aceitáveis argumentativa, política e eticamente. C abe ao debate público e às lutas sociais definirem essecontencioso. A qui, a posição dos cientistas sociaissedividirá entrevárias posições, ainda quando cerrando fileiras em relação aos dois princípiosinegociáveisacimamencionados. Além disso, questionar a neutra lidadeem nomedainclusividadejamais poderátransigir quanto ao asseguramento decondições institucionaiselegaisquenão apenaspermitam a expressão do dissenso em matérias que mobilizem valores ou interesses dos(as) cidadãos(ãs), mastambém protejam maiorias eminorias do arbítrio, da violência, do vitupério, da dominação. 0 ponto é, antes, quenoslimites deuma adesão aosval ores deigual dadeeliberdade para todos da democracia moderna háuma grandemargem para o exercício do agonismo pluralista sem queo caráter democrático, laico ou republicano da ordem pública esteja em risco. D eoutro lado, seatendência a articular republicanismo com reconhecimento da pluralidadesocial for acolhida como o mais novo desenvolvimento do discurso democrático-radical, a heterogeneidade da representação, da pauta de temas sob polêmica e de repertórios de ação aumentará, não diminuirá. D esse cenário complexo, as expressões religiosas, reacionárias, moderadas e progressistas são hoje parteinquestionável.

0 lugar do pesquisador: mediador e ator

O s elementos descritivos e normativos dos processos apresentados suscitam tanto a atores como a analistas acadêmi cos uma série de desafios que requerem reflexão conceitual e imaginação para respondêlos. Q ue fazer diante de discursos convincentes, porém contrários ao que defende (e não apenas constata) o pesquisador? Como se posicionar ante as insistentestoma das de opinião junto a intelectuais sobre o que acham (ou sabem) das ques- 
19. N ão há espaço para articular a posição aqui defendida, mas diga-se brevementequesetrata de um reconhecimento o mais rigoroso possível dacontingência edalocalidadedossistemasde práticasevaloresqueinformam a ação individual ecoletivanassociedades ocidentais contemporâneas, sem perder devistaqueosatores sociaisnão sedeixam paralisar pela percepção ou pelo reconhecimento dessas duas condições: porque elas se definem precisamente pela fronteira que ao mesmo tempo liga e separa as identidades (pessoais, coletivas, organizacionais, nacionais etc.), afirmar-seedisputar espaços de poder e visibilidade tornam-se sinônimos. tões envolvendo religião e política no calor das conjunturas eleitorais, nos debates na mídia, nos espaços de aconselhamento e consultoria dados a gestores públicos ou lideranças populares? O nde traçar a fronteira entre saber, convicção pessoal, desejo e incerteza ao tomar posição como acadê mico nesse emaranhado de questões nada neutras ou sem conseqüência?

Precisamosnada menosque de uma articulação teórica das novas relações entre religião e política. Se é verdade que as mudanças em curso estão a pôr em xequeconcepções desociedadeeEstado, da mudança social, da constituição do político na contemporaneidade, al go precisa ser feito no sentido de aproximar o "trabalho da teoria" do "trabal ho da análiseempírica" edo debatepúblico, envolvendo earticulando distintos registros deprodução desaberes, de modo a contribuir para que transformações desejadas de sentido emancipatório venham a se concretizar. Sever, como dissemos, étomar posição, queinjunçõesdessa tomada delugar estão postaspara osanalistas dosfenômenos religiosos contemporâneos com incidência política?

D ada a história da configuração desses registros(suas dimensõese culturas institucionais, especialização eesferas deincidência), háa necessidade deexercícios de tradução por meio dos quais os espaços públicos de prática de reflexividade social possam se beneficiar de distintas, mas limitadas, contribuições - o discurso teórico, o empírico-analítico e o dos atores sociais, com suas linguagens, formas de atuação e de produção de saber específicas - , articulando novos discursos em torno de temas ou objetivos comuns, sem dissolver a especificidade de cada discurso "original" (cf. N unes, 2002, pp. 328-331; Santos e N unes, 2003, p. 40). Esse trabalho de tradução torna 0 pesquisador um mediador cultural, mastambém um ator envolvido, implicado performativamente no que está acontecendo.

Produzir conhecimento articulando saberes étambém se posicionar num campo de forças e nele incidir; não há mais o espectador intelectual, pois os atores cada vez mais interagem e "pactuam" a disponibilização e o recebimento da informação e da análise vinda da prática de pesquisa. N o entanto, no contexto de pluralização, relativização de fronteiras e contestação de identidades fixas em que tal mediação e agência se dão, tampouco há uma única forma de articulação e expressão. Sem propor uma postura relativista ${ }^{19}$, pode-se dizer queser mediador eator éalgo quesecombina sincronicamente, se alterna diacronicamente ou conflita por um período ou intermitentemente. Por outro lado, as saí das en contradas para equacionar o caráter nãonecessário dessa articulação não são virtuosas em si, dependem das relações nas quais se inserem e dos efeitos hegemônicos que logram produzir. 
Esse é um terreno cuja compreen são, estamos convictos, nos é assistida pelos discursos críticos vindos de várias abordagens "pós". Segundo N unes, trata-se de passar de uma política da representação para uma política performativa da articulação:

A articulação designa simultaneamente uma "correspondência não-necessária" entre elementos diferentes e uma "performance" que realiza praticamente essa correspondência (H ebdige [...]), e que permite dar um conteúdo positivo à idéia de que "difference connects" (Jameson [...]). Esses elementos diferentes que são articulados podem corresponder a constelações de pertenças e de subjectividades sociais que, não sendo necessariamente coerentes entre si, coexistem nos mesmos indivíduos. 0 acionamento selectivo e em situação dessas pertenças e subjectividades permitenos, com $\mathrm{H}$ ebdige, descrever o pesquisador, na sua relação com os "terrenos" ou "objectos" de pesquisa, como uma "testemunha articulada", uma testemunha de processos e acontecimentos posicionados num terreno, contraposta à concepção convencional do pesquisador como observador ou etnógrafo, produtor de um conhecimento (ainda que reflexivo, multivocal ou dialógico), posicionado ou não, de um terreno (2002, p. 330).

Esse entendimento representa um notável paralelo com a teoria do discurso, pela qual Ernesto Laclau, C hantal M ouffeeoutrostêm proposto uma concep ção da política como ontologia do social, a partir da generalização da categoria "hegemonia", entendida como articulação de vontades coletivas a partir de terrenos marcados pelo antagonismo ${ }^{20}$ eo deslocamento ${ }^{21}$. 0 pósmarxismo dessa orientação teórica tira conseqüências da guinada cultural querepôsa ênfase no simbólico como dimensão constitutiva do real, levando a uma ampliação do sentido do termo "discurso" para além do puramente lingüístico ou ideativo -; do pluralismo ideológico - tornado princípio ético-político eepistemológico - ; eda democracia como articulação tensa entre igual dadeediferença- radicalizando-a paraalém da idéia de regime político (ou pelo menos entendendo-o num sentido mais "antigo", como ressalta Claude Lefort, enquanto "forma desociedade") ${ }^{22}$.

A teoria do discurso ea teoria crítica ligadaà contribuição de Boaventura Santos (a que N unes se filia) podem, nesse sentido, ajudar bastante a um duplo objetivo teórico: a) articular os discursos da teoria, da análise sociológico-político-antropológica empírica e dos atores sociais, por meio de uma tradução que não funde, dissolve ou substitui os mesmos, mas permite que se reconheça parte de projetos práticos comuns; b) articular debates
20. Por antagonismo Laclau não entende apenas umarelação objetiva de confronto entreduas ou maisforças sociais. 0 antagonismo designa a contestabilidade que representa 0 limite de toda objetividade, ordem ou siste$\mathrm{ma}$, efeito de processos de exclusão anterior ou do traçado "atual" de uma fronteira pelaqual se define um dentro e um fora, um nós e um eles. $N$ ão é necessário, para a emergência do antagonismo, que haja contradição ou inimizade objetiva entre as forças em confronto. Bastaquerepressões, insatisfações, recomposição de forças derrotadas ou excluídas anteriormenteexplicitem a pretensão de toda ordem deimpor-sesobre todos os elementosque articula.

21. Dimensão complementar à do antagonismo, designaasuscetibilidade de toda ordem ou projeto hegemônico à crise, ao fracasso em implementar-seplenae definitivamente e à contestaçãa. 0 deslocamento testemunhaainda o caráter contingente de toda ordem, por mais duradoura que 
seja, expressando-sepor meio de acontecimentos que transtornam, subvertem ou abalam a ordem vigente, para além de seu controle e capacidadedeprevisão.

22. Para algumas referências relevantes desse enfoque, ver Laclau e M ouffe (1989, 1993); Laclau (1994, 2000, 2005); M ouffe (1992, 1996, 2000); H owarth et al. (2000); Butler, Laclau eZizek (2000); Amaral Jr. e Burity (2006); Soares (1996).

23. Há, sim, múltiplas formas de mobilização e organização de atores religiosos, em grupos ou até oficialmente em nome de igrejas e religiões estabelecidas, a despeito das muitas interpretações que recebem eque, a rigor, não deixam de ter impacto sobreo quedefineesses fatos como tais.

24. Aindaqueestarapidamente passe do momento da decisão - ou seja, de constituição do sujeito - ao da sua acomodação a uma das posçōesdesuje to constituídas no processo, eque, tendo começado como inovação, ruptura, mudança incremental, siga nadireção dainstitucio- sobre pluralidade cultural e social, democracia e republicanismo num único marco referencial, novamente traduzindo-os de modo a "hegemonizar" novos projetos.

\section{Algum arremate}

Q uis neste trabalho argumentar em defesa de uma complexa operação que, partindo de uma filiação temática edisciplinar confessada, uma análise sociológica e politológica das relações entre religião e política encontra-se em seu percurso com as demaisciências sociais dareligião epropõe-/hesuma agenda que vai muito além de sua especificidade. Ao mesmo tempo, quis delimitar a empreitada num campo de assumida reflexividade, sem recorrer ao subjetivismo de inscrever escolhas nos limites de uma mera biografia. Procurei distinguir analiticamentetrêsmomentosquevia deregrasecombinam ou diluem em muitas análises, equerequerem, a meu ver, numa discussão como a proposta, pelo menos al guma explicitação - o momento da observação empírica, o da interrogação analítica e 0 da tomada de posição ético-teórica eético-política.

Sendo uma reflexão sobre o enigma e as incertezas em torno da emergência pública das religiões em várias partes do mundo, mas que tal vez não tivesse tanta pungência se não se tratasse de um processo escancarado no Brasil, o fio condutor de nossa argumentação foi uma proposta de "acolhimento dos fatos" 23 e de sua inscrição num contexto que é, ao mesmo tempo, singularizantee desterritorializante. Exige compreender a contingência das experiências e identificar linhas de força e ten dências estruturais de que são parte e cúmplices. U m contextualismo que não impede conclusões generalizantes, mas não as faz em nome de determinações inapeláveis ou subtraídas à ação do sujeito ${ }^{24}$.

0 teor "normativo" da análise definiu-se em termos de uma crença na superioridade de um entendimento agonístico epluralista da ordem democrática, sensível à lógica das demandas culturais contemporâneas como possibilitadoras de uma mais justa acomodação das diferenças, sem tomá-las como intrinsecamente virtuosas nem viciosas. Assim, também não precisamos assentar a análisena idéia de um amplo consenso ou do ajuste das concepções do bem de cada campo deatoresa um espaço público sanitizado. Se a secularização da política pode ensinar al go neste particular é a virtude da desdramatização da ameaça religiosa, em favor de uma abordagem quehaure da comparação a relativização de certos impasses, temores e triunfalis- 
mos. $N$ ão é bem esse o clima apreensivo e algo confuso do debate que enfrentamos na cena pública brasileira. 0 momento é de dramatização, de temores, recusas, diálogos ásperos, como diria Luiz Eduardo Soares. A revivescência do discurso republicanista em curso torna-se, a despeito de tudo isso, mais uma oportunidade para tornar a esfera pública mais inclusiva (não neutra, embora exigente de respeito às regras e aos val ores fundamentais que nelas se encarnam) em relação às identidades quenela se movimentam em busca não só de representação de interesses, mas também de reconhecimento. Ampliar o cânone do reconhecimento, da diferença e da igualdade, poderíamos dizer com SantoseN unes (2003): eis aí um trabal ho tão promissor quanto árduo e incerto. Aqui, nenhuma convicção de posse da verdade, religiosa ou não, fará o truque.

\section{Referências Bibliográficas}

"Abaixo-ASSIn Ad o reúne 25 mil contra projeto". (2007), Folha deS. Paulo, disponível em http://www1.folha.uol.com.br/fsp/ilustrad/fq1606200710.htm, consultado em 25/6/2007.

Am aral JR., Aécio \& Burity, Joanildo A. (orgs.). (2006), Indusão social, identidade e diferença: perspectivas pós-estruturalistas de análise social. São Paulo, Annablume.

Am m erm An , N ancy. (1997), "O rganized religion in a voluntaristic society". Sociology of Religion, 58 (3): 203-215.

Angrosin 0, M ichael V. (2003), "L'Arche: the phenomenology of Christian counterculturalism". Qualitative Inquiry, 9 (6): 934-954.

Bat ISTA, Carla \& M AiA, M ônica (orgs.). (2006), Estado laico eliberdades democráticas. Recife, SO S Corpo.

Beckford, James \& Gilliat, Sophie. (2005), Religion in prison: "equal rites" in a multi-faith society. Cambridge, C ambridge U niversity Press.

Berger, Peter L. (1999), "The desecularization of the world: a global overview". In: . (ed.), The desecularization of theworld: resurgent religion and world politics. Washington/G rand Rapids, Ethics and Public Policy Center/Eerdmans.

BeYER, Peter. (1994), Religi on and globalization. Londres/N ew D elhi, Thousand 0 aks/ Sage.

Bıgnotto, Newton (org.). (2000), Pensar a República. Belo Horizonte, Editora da UFMG.

BIN GEM ER, M aria C lara (org.). (1998), 0 impacto da modernidade sobrea religião. São Paulo, Loyola. nalização. Portanto, afirmamoso lugar do sujeito, sim, mas não compartilhamos visões voluntaristas ou autonomistas: só há sujeito no momento da decisão, mas, uma vez tomada, esta última define uma nova ordem, um novo marco discursivo, nos quais o que há são posiçõesdesujeito, limitadas elimitantes. 
Bırman, Patrícia (org.). (2003), Religião e espaço público. São Paulo, Attar/CN Pq/ Pronex.

. (2004), “M ovimentos cívico-religiosos no Rio de Janeiro e alguns de seus impasses: 0 caso do M ural da D or". In: BiRm An, Patrícia \& Leite, Márcia Pereira (orgs.), U m mural para a dor: movimentos ćivico-religiosos por justiça e paz. Porto Alegre, UFRGS, pp. 221-286.

Birm an, Patrícia \& LeITe, M árcia Pereira (orgs.). (2004), U m mural para a dor: movimentos ćvico-religiosos por justiça e paz. Porto Alegre, Editora da U FRGS.

Bittencourt Filho, José. (2003), M atriz religiosa brasileira: religiosidade e mudança social. Petrópolis/Rio de Janeiro, Vozes/Koinonia.

Bo ввı , N orberto \& VIROLI, M aurizio. (2007), D ireitose deveres na república: os grandes temas da política e da cidadania. Rio de Janeiro, Campus/Elsevier.

BURITY, Joanildo A. (1994), Radical religion and the constitution of new political actors in Brazil: the experience of the 1980s. Colchester. Tese de doutorado em Ciência Política. Essex U niversity, mimeo.

. (1997), I dentidade e política no campo religioso: estudos sobre cultura, pluralis mo e o novo ativismo eclesial. Recife, IPESPE/U FPE.

. (1998), "Cultura política democrática e atores religiosos". Relatório de pesquisa. Recife, Fundação Joaquim N abuco, mimeo.

. (2000), "Cidadãos, consumidores, militantes e fiéis: pertencimento e democracia”. Relatório de pesquisa. Recife, Fundação Joaquim N abuco, mimeo.

. (2001a), "Religião e política na fronteira: desinstitucionalização e deslocamento numa relação historicamente polêmica". Rever, 4, disponível em http:// pucsp.br/rever/4/t_burity.htm.

. (2001b), "I dentidade e múltiplo pertencimento nas práticas associativas locais". Cadernos de Estudos Sociais, 17 (2): 189-228, Recife, Fundação Joaquim Nabuco.

(2002a), “M udança cultural, mudança religiosa e mudança política: para onde caminhamos?". In: (org.), Cultura eidentidade: perspectivas interdisciplinares. Rio de Janeiro, D P\&A, pp. 26-48.

. (2002b), "C ultura e cultura política: sobre retornos e retrocessos". Revista de Ciências Sociais, 33 (1): 7-31.

. (2003a), "Religião e redes nas políticas sociais: legitimando a participação das organizações religiosas". Estudos de Religião, XVII (25): 12-47.

. (2003b), "N ovas cartografias do sagrado: religião e religiosidade num contexto plural e em deslocamento". Trabalho apresentado no GT Religião e Sociedade, no XXVII Encontro Anual da Anpocs. Caxambu, M G, mimeo.

. (2005a), "Identidades coletivas em transição e a ativação de uma esfera pú- 
blica não-estatal". In: Lubam Bo, Cátia, BAnd EIRA, D enílson \& M elo, M arcus (orgs.), D esenho institucional e participação política: experiências no Brasil contemporâneo. Petrópolis, Vozes, pp. 63-107. . (2005b), "Religião e república: desafios do pluralismo democrático". Cadernos de Estudos Sociais, 21 (2): 23-41, jul.-dez.

. (2006a), "Reform of the State and the new discourse on social policy in Brazil". Latin American Perspectives, 33 (3): 67-88.

. (2006b), "R eligião, voto e instituições políticas: notas sobre os evangélicos nas eleições 2002". In: BuRITY, Joanildo \& M ACHADO, M aria das D ores $C$ ampos (orgs.), O svotos de D eus, evangéli cos, polític ca ele ções no Brasil. Recife, M assangana. . (2006c), Redes, parcerias e participação religi osa nas políticas sociais no Brasil. Recife, M assangana. . (2007a), "Trajetórias da religião e da modernidade: a narrativa histórica de uma objeção". Estudos de Sociologia, 13 (12): 19-48.

. (2007b), "O rganizações religiosas e ações sociais: entre as políticas públicas e a sociedade civil". Anthropológicas, 18 (2): 7-48.

. (2008), “Brazil's rise: Inequality, cultureand globalization”. Journal of Futures, v. 40, doi:10.1016/j.futures.2008.02.001.

BuRITY, Joanildo A. \& M ACHADO, M aria das D ores C ampos (orgs.). (2006), O s votos de $D$ eus, evangélicos, política e eleições no Brasil. Recife, M assangana.

Butler, Judith, Laclau, Ernesto \& Zizek, Slavoj. (2000), Contingency, hegemony, universality: contemporary dialogues on the left. Londres, Verso.

CARD o so, Sérgio (org.). (2004), Retorno ao republicanismo. Belo H orizonte, Editora daUFM G.

Casan ova, José. (1994), Public religions in the modern world. Chicago, Chicago University Press.

CASTILH os, Washington. (2007), "Laicidade à prova”. Sexuality Policy Watch. Disponível em http://www.sxpolitics.org/mambo452/index.php?option=com_content $\&$ task=view $\&$ id=100\& Itemid=123, consultado em 1/7/2008.

Chand DLR, D avid. (2000), "Active citizens and the therapeutic state: the role of democratic participation in local government reform". Policy \& Politics, 29 (1): 3-14.

Chaves, M ark. (2001), "Religious congregations and welfare reform". Society, 25 (1): 21-27, January/February.

Совв JR., John B. (2001), Postmodernism and public policy: reframing religi on, culture, education, sexuality, dass, race, politics, and the economy. Albany, StateU niversity of N ew York.

Cochran, ClarkeE. \& Cochran, D avid C arroll. (2003), Catholics, politics, and public policy: beyond left and right. M aryknoll, O rbis Books. 
Conn olly, W illiam E. (1999), Why I am not a secularist. M inneapolis/Londres, University of M innesota.

C on RAd o, Flávio César. (2005), A ção Social Evangélica: projetos sociais: regiões metropolitanas de Belo H orizonte, Rio de Janeiro e Campinas. Rio de Janeiro, Iser.

C OSTA, Sérgio. (2003), As cores de Erćlia: effera pública, democracia, configurações pós nacionais. Belo H orizonte, Editora da UFM G.

DAVIDSON, Alastair. (1999), "O pen republic, multiculturalism and citizenship: the French debate". Theory \& Event, 3 (2).

Dionne JR., E. J. \& Chen, M ing H su (eds.). (2001), Sacred places, civic purposes: should government help faith-based charity?. Washington, D.C., Brookings Institution.

"Ensino religioso obrigatório em escolas". (2008), Causa O perária online, http:// www.pco.org.br/conoticias/ler_materia.php?mat=7505, consultado em 15/7/2008.

Esposito, John L. \& W ATSO N, M . (eds.). (2000), Religion and the global order. Cardiff, University of Wales.

Ferrare, Carol. (2007), "Resistência religiosa”. Congresso em Foco, disponível em http:/ /congressoemfoco.ig.com.br/N oticia.aspx?id=17131, consultado em 10/06/2008.

Filoramo, Giovanni \& Prandı, Carlo. (2003), As ciências das religiões. 3. ed. São Paulo, Paulus.

Fischm ann, Roseli. (2007), "O projeto ‘D eus na escola' deve ser sancionado?". Folha de S. Paulo, disponível em http://www1.folha.uol.com.br/fsp/opiniao/ fz2909200708.htm, consultado em 30/09/2007.

Fraser, N ancy. (2001), "D a redistribuição ao reconhecimento? D ilemas da justiça na era pós-socialista". In: SouzA, Jessé (org.), D emocracia hoje: novos desafios para a teoria democrática contemporânea. Brasília, Editora da UnB, pp. 245-282.

Freire-M edeiros, Bianca \& Chinelli, Filippina. (2003), Favela e redes solidárias: formas contemporâneas de mobilização e organização popular no Rio de Janeiro. CSU IM Working Paper \# 02-BRA-01. Austin, C enter for the Study of U rbanization and Internal M igration in D eveloping Countries/University of Texas, August.

Freston, Paul C. (1993), Evangéli cosepolítica no Brasil: da Constituinte ao impeachment. Campinas. Tese de doutorado. Universidade Estadual de Campinas, mimeo. . (2004), Evangel icalsand politicsin Asia, Africa and Latin America. Cambridge, Cambridge University Press.

G ARCIA, Gilberto. (2005), "O estado laico é fundamento da República”. O bservatório da Imprensa, disponível em http://observatorio.ultimosegundo.ig.com.br/ artigos. asp?cod=328C ID 002, consultado em 22/4/2008.

G IU m BelLI, Emerson. (2002), 0 fim da religião: dilemasda liberdade religiosa no Brasil e na França. São Paulo, Attar. 
Grum An, M arcelo. (2005), "O lugar da cidadania: Estado moderno, pluralismo religioso e representação política”. Revista deEstudos da Reli gião, 1: 95-117. D isponível em www.pucsp.br/rever/rv1_2005/p_gruman.pdf.

Gurney, Robin, H Adsell, H eidi \& M udge, Lewis (eds.). (2006), Beyond idealism: a way ahead for ecumenical social ethics. Grand Rapids/C ambridge (UK), W illiam E. Eerdmans.

H ABERM AS, Jurgen. (2004), A inclusão do outro: estudos de teoria política. 2. ed. São Paulo, Loyola.

H ALL, Stuart. (2003), D a diáspora: identidades e mediações culturais. Belo H orizonte/ Braślia, Editora da U FM G/Representação da U nesco no Brasil.

H AYN ES, Jeff. (1998), Religion in global politics. Londres/N ova York, Longman.

HeCLO, Hugh \& M CCLAY, Wilfred M. (eds.). (2003), Religion returns to the public square: faith and policy in America. Washington, Woodrow W ilson Center.

Hermet, Guy. (2002), Cultura e desenvolvimento. Petrópolis, Vozes.

H eRvieu-LÉGER, D anièle. (1997), "Representam os surtos emocionais contemporâneos o fim da secularização ou o fim da religião?". Religião e Sociedade, 18 (1): 31-48.

H owarth, D avid, N orval, Alleta J. \& Stavrakakis, Yannis (eds.). (2000), D iscourse theory and political analysis: identities, hegemonies and social change. $M$ anchester/ $\mathrm{N}$ ova York, $\mathrm{M}$ anchester University.

Jen NINGS, Jeremy. (2000), “C itizenship, republicanism and multiculturalism in contemporary France". British Journal of Political Science, 30: 575-598.

Kennedy, Sheila Suess \& Bielefeld, Wolfgang. (2002), "Government shekels without government shackles? T he administrative challenges of Charitable $\mathrm{C}$ hoice". Public Administration Review, 62 (1): 4-11, January/February.

KoSHY, N inan (ed.). (2002), Globalisation: the imperial thrust of modernity. Bossey/ M umbai, Ecumenical Institute/Vikas Adhyayan Kendra.

Kym LickA, W ill. (1998), Ciudadanía multicultural: una teoría liberal de los derechos de las minorías. Barcelona/Buenos Aires/M éxico, Paidós.

. (2000), "A N orth American view" (Review symposium: Report of the Commission on the Future of M ulti-Ethnic Britain: UK, N orth American and Continental European perspectives). Journal of Ethnic and M igration Studies, 26 (4): 723-731, 0 ctober.

LACLAU, Ernesto (ed.). (1994), Themaking of political identities Londres/N ova York, Verso. . (2000), "Identity and hegemony: the role of universality in the constitution of political logics". In: Butler, Judith, LaCLau, Ernesto \& Zizek, Slavoj. Contingency, hegemony, universality: contemporary debates on the left. Londres/N ova York, Verso, pp. 44-89.

. (2005), La razón populista. Buenos Aires, Fondo de Cultura Económica. 
Laclau, Ernesto \& M ouffe, Chantal. (1989), H egemony \& socialist strategy: toward radical democratic politics. Londres, Verso.

. (1993). "Posmarxismo sin pedido de disculpas". In: Laclau, Ernesto. N uevas reflexiones sobre la revolución de nuestro tiempo. Buenos Aires, Nueva Visión.

LAN DIM , Leilah (org.). (1998), A ções em sociedade: militância, caridade, assistência etc. Rio de Janeiro, $\mathrm{N}$ au.

Lara, M aría Pia. (2002), "D emocracy and cultural rights: is there a new stage of citizenship?". Constellations, 9 (2): 207-220.

LoreA, Roberto Arriada (org.). (2008), Em defesa das liberdades laicas. Porto Alegre, Livraria do Advogado.

Lupu, I ra C . \& T utTLE, Robert W. (2002), Government partnerships with faith-based service providers: the State of the law. Albany/Washington, N elson A. Rockefeller Institute of G overnment/State U niversity of N ew York/G eorge Washington U niversity Law School.

M ACHADO, M aria das D ores Campos. (2005), "Religião, política e assistencialismo no estado do Rio de Janeiro". Praia Vermelha, 12: 64-89.

M ACH ADO, M aria das D ores C ampos \& M ARIz, Cecília L. (1999), "M udanças recentes no campo religioso brasileiro". Antropolítica, 5: 21-44.

M ALLIM ACI, Fortunato. (2008), "Las paradojas y las múltiples modernidades en Argentina". In: (org.), M odernidad, religión y memoria. BuenosAires, C olihue, disponível em http://www.ceil-piette.gov.ar/investigadores/fmallimacipub/ 2008cpara.pdf.

M Aтo, D aniel. (2004), "Redes transnacionales de actores globales y locales en la producción de representaciones de ideas de sociedad civil". In: MATO, Daniel (org.), Políticas de ciudadanía y sociedad civil en tiempos de globalización. Caracas, Faces/U niversidad Central de Venezuela, pp. 67-93.

M EN DES, Candido (org.). (2005), Cultura, política y sociedad: perspectivas latinoamericanas. Buenos Aires, Clacso.

. (2008). "O Supremo de costas para D eus?". Folha de S. Paulo, disponível em http://www1.folha.uol.com.br/fsp/opiniao/fz2204200809.htm, consultado em 22/ 4/2008.

M ODOOD, Tariq. (1998), "Anti-essentialism, multiculturalism and the 'recognition' of religious groups". Journal of Political Philosophy, 6 (4): 378-399. . (2005a), M ulticultural politics: racism, ethnicity and musims in Britain. M inneapolis, U niversity of $M$ innesota. . (2005b), "Remaking multiculturalism after 7/7". O pen D emocracy, disponível em www.opendemocracy.net/conflict-terrorism/multiculturalism_2879.jsp, consultado em 29/9/2005. 
M ouffe, Chantal (ed.). (1992), D imensi ons of radical democracy: pluralism, citizenship, community. Londres/N ova York, Verso.

. (1996), D econstruction and pragmatism. Londres/N ova York, Routledge. . (2000), The democratic paradox. Londres/N ova York, Verso.

N unes, João Arriscado. (2002), "Teoria crítica, cultura e ciência: o(s) espaço(s) e o(s) conhecimento(s) da globalização". In: SAn tos, Boaventura de Sousa (org.) , A globalização e as ciências sociais. 2. ed. São Paulo, Cortez, pp. 301-344.

O ro, Ari Pedro. (2003), "A política da I greja U niversal e seus reflexos nos campos religioso e político brasileiros". Revista Brasileira de Ciências Sociais, 18 (53): 53-69.

O Ro, Ari Pedro \& StelL, Carlos Alberto (orgs.). (1997), Religião e globalização. Petrópolis, Vozes.

O RTIz, Renato. (2001), "Anotações sobre religião e globalização”. Revista Brasilei ra de Ciências Sociais, 16 (47): 59-74, out.

PAREKH, Bhikhu. (2002), Rethinking multiculturalism: cultural diversity and political theory. Cambridge, M A, H arvard University.

Parker G., C ristián. (1999), "G lobalización, diversidad religiosa y democracia multicultural". Religião \& Sociedade, 20 (1): 9-38, abr.

PierucCl, Antônio Flávio. (1997), "Reencantamento e dessecularização: a propósito do auto-engano em sociologia da religião". N ovos Estudos Cebrap, 49: 99-117, nov.

Pieruccl, Antônio Flávio \& Prand d, Reginaldo. (1996), A realidade social das religiões no Brasil. São Paulo, H ucitec.

Quiroga, Ana M aria, C on Rado, Flávio C ésar \& N Ascim Ento, M arcelo. (2005), A ção Social Evangélica: sumário executivo. Rio de Janeiro, Iser, mimeo.

Rich ARd SON, James T. (ed.). (2003), Regulating religion: case studies from around the globe. N ova York, Kluwer Academic/Plenum Publishers.

Riesen BRODT, M artin. (2000), "Secularization and the global resurgence of religion". Trabalho apresentado no C omparativeSocial Analysis Workshop, promovido pelo D epartamento de Sociologia da University of California, Los Angeles, março. D isponível em http://www.sscnet.ucla.edu/soc/groups/ccsa/riesenbrodt.pdf.

Robertson, Roland. (1989), "Globalization, politics and religion". In: BECKFord, James A. \& Luckmann, Thomas (eds.), The changing face of religion. Londres, Sage/ISA.

Roof, Wade Clark (ed.). (1991), World order and religion. Albany, State University of $\mathrm{N}$ ew York.

SAn ChIs, Pierre (org.). (2001), Fiéis e cidadãos: percursos de sincretismo no Brasil. Rio de Janeiro, Editora da UERJ.

SAntos, Boaventura de Sousa. (2002), "O s processos da globalização". In: SAntos, 
Boaventura de Sousa (org.), A globalização e as ciências sociais. 2. ed. São Paulo, Cortez.

SAntos, Boaventura de Sousa \& N un ES, João Arriscado. (2003), "Introdução: para ampliar o cânone do reconhecimento, da diferença e da igualdade". In: SAntos, Boaventura de Sousa (org.), Reconhecer para libertar: os caminhos do cosmopolitis mo multicultural. Rio de Janeiro, Civilização Brasileira, pp. 25-68.

Sardin ha, Edison. (2007), "C ruzada contra a Lei da H omofobia”. Congresso em Foco, disponível em http://congressoemfoco.ig.com.br:80/N oticia.aspx?id=19542, consultado em 18/7/2008.

Scherer-W arren, Ilse. (1999), Cidadania sem frontei ras: ações coletivas na era da globalização. São Paulo, Hucitec.

Segato, Rita Laura. (2007), "A faccionalização da república e a paisagem religiosa como índice de uma nova territorialidade". H orizontes Antropológicos, 13 (27): 99-143, jan.-jun.

Shachar, Ayelet. (2000), "On citizenship and multicultural vulnerability". Political Theory, 28 (1): 64-89, February.

SOARES, Luiz Eduardo. (1996), "Globalization as a shift in intracultural relations". In: So Ares, Luiz Eduardo (ed.), Cultural pluralism, identity, and globalization. Rio de Janeiro, Unesco/ISSC/C onjunto U niversitário C andido M endes, pp. 363-392.

Starling, H eloísa M aria M urgel (org.). (2003), "D ossiê Brasil República”. Revista USP, 59, set.-nov.

Swatos Jr., William H. (ed.). (1989), Religious politics in global and comparative perspective. Westport, Greenwood.

Tomassinı, Luciano. (2000), "El giro cultural de nuestro tiempo". In: Kliksberg, Bernardo \& T o m ASSINI, L uciano (orgs.), Capital social y cultura: claves estratégicas para el desarrollo. Buenos Aires/M éxico, Banco Interamericano de Desarrollo/ Fundación Felipe Herrera/Universidad de M aryland/Fondo de Cultura Económica, pp. 59-100.

Turner, Bryan S. (2006), "Religion”. Theory, Culture \& Society (Problematizing global knowledge: Special issue), 23 (2-3): 437-455, M arch-M ay.

Vasquez, Manuel A., Peterson, Anna Lisa \& Williams, Phillip J. (eds.). (2001), Christianity, social change, and globalization in the Americas. Piscataway, $\mathrm{N}$ J, Rutgers University. 


\section{Resumo}

Religião, política e cultura

Este artigo se propõe a ser uma metareflexão sobre a construção de uma interrogação quanto ao vínculo entre religião e política na contemporaneidade. 0 que vemos entre religião e política na contemporaneidade? Como nos posicionamos - para ver e em face de que vemos? Q ue lugar é esse do/no qual vemos? Essas questões são formuladas ao longo do texto, a partir do que seria o cenário perceptível das relações entre religião e política: a) no plano da cultura e do cotidiano, da esfera pública e da política, os atores religiosos se movimentam e trazem a público sua linguagem, ethos, demandas, nas mais diversas direções; b) isso ora contribui para caracterizar formas pluralistas e dialógicas, ora aponta para o estreitamento dos canais de comunicação e para a escalada da violência e da intolerância; c) articulando ou deixando-se cruzar por questões de identificação nacional/étnica/racial/de gênero/de classe/etária e reivindicações políticas, tais processos geram "reconhecimentos", "valorizações" e "diálogos" entre atores laicos e religiosos. 0 cenário suscita reposicionamentos temáticos e teóricos dos cientistas sociais, que são identificados e discutidos no texto.

Palavras-chave: Religião e política; Religião - M etodologia; Religião e cultura; Abordagens teóricas da religião.

\section{Abstract}

Religion, politics and culture

This article is offered as a meta-reflection on the links between religion and politics in the contemporary world. What do we see? H ow do we position ourselves - both in order to see and in response to what we see? What is this place in/from which we see? These questions are posed over the course of the text, which pursues the following hypotheses: a) at the level of culture and everyday life, the public sphere and politics, religious actors circulate and publicly express their language, ethos and demands, with a variety of implications; b) this either contributes to the emergence of pluralistic and dialogic forms, or indicates a narrowing of the communication channels and the escalation of violenceand intolerance; c) processes of 'recognition,' 'acknowledgment' and 'dialogue' between lay and religious actors are thereby generated through theinterconnecting of issues of national/ethnic/racial/gender/class/age identification and political demands. Such a scenario elicits thematic and theoretical repositionings from social scientists, which are identified and discussed in the text.

Keywords: Religion and politics; M ethodology of religion; Religion and culture; Theoretical approaches to religion.

Texto recebido e aprovado em 8/8/2008.

Joanildo A. Burity é pesquisador titular e D iretor de Pesquisas Sociais da Fundação Joaquim Nabuco, e professor das pós-graduações em Sociologia e Ciência Política da Universidade Federal de Pernambuco. Email: joanildo.burity@ fundaj.gov.br. 